Article

\title{
Time in the Upanișads
}

\section{Signe Cohen}

Department of Religious Studies, University of Missouri, Columbia, MO 65211-7090, USA; cohens@missouri.edu

Received: 21 November 2019; Accepted: 24 January 2020; Published: 28 January 2020

\begin{abstract}
The Upanișads (ca. 800 BCE) were composed during a transitional time period in Hinduism when Vedic ritual and cosmogonic ideas began to give way to new worldviews. The intriguing Upanișadic notions of time have received little attention in the scholarly literature compared to the elaborate models of cyclical time that develop in later texts. I propose, however, that the Upanișads represent a seminal reorientation in Hindu conceptions of time. We still find an older view of time in the Upanișads as something that marks the rhythms of the ritual year, but later Upanișadic texts begin to explore entirely new ways of thinking about time. I propose that the movement away from the more integrated view of the material and immaterial as one reality in the Vedas towards a radical dualism between the spiritual and the material in later Hindu thought informs many of the new ideas of time that emerge in the Upanișads, including that of time as an abstract construct. The authors of the Upanișads investigate-and ultimately reject — the notion of time itself as the cause of the visible world, ponder the idea that time is something that is created by a divine being in order to structure the world, speculate that time may be a mere intellectual construct, and postulate that the highest reality may be situated in a realm that is outside of time altogether.
\end{abstract}

Keywords: Upaniṣads; Hinduism; time

The Upanișads (ca. 800 BCE) were composed during a transitional time period in early Indian thought when old Vedic ritual and cosmogonic ideas began to give way to new worldviews. The Upanișadic notions of time have received relatively little attention in the scholarly literature compared to the concepts of time in the classical schools of Hindu philosophy (Das 1933; Hiriyanna 1939; Herbert 1963; Bhattacharya 1965; Mandal 1968; Sen 1968; Bhaduri 1975; Mahadevan 1976; Mahadevan 1977; Balslev 1992) or the elaborate models of the yugas and kalpas that develop in later texts (Mandal 1968; Balslev 1992; Gonzalez-Reimann 2002). ${ }^{1}$ I propose, however, that the Upanisads represent a seminal reorientation in Hindu conceptions of time. This paper argues that we see a shift in the views of time from earlier to later Upanișads that mirrors the increasing abstraction of Hindu thought in this time period. The Vedic view of the material and immaterial as one integrated reality gives way to a radical distinction between the spiritual and the material in much of later Hindu philosophy. I argue that this shift informs many of the ideas of time that become prominent in the Upanișads, including that of time as an abstract entity. Drawing on Bakhtin's notion of the literary chronotope (Bakhtin 1981), I propose that the emerging Upanișadic narratives of transcendence necessitate new understandings of both space and time. The development of new ideas of time throughout the Upaniṣads is closely related to

1 Although several scholars have referred to the view of time found in classical Hindu and Buddhist texts as "cyclical" (see for example Eliade 1954, 1958; Gupta 1973; Lannoy 1974), both Sharma (1974) and Collins (1998) have demonstrated that this model is far too simplistic to cover the varied models of time in classical Indian thought. Collins refers to the pervasive idea in Western scholarship that there exists a clear distinction between Western linear time and Indian cyclical time as "the myth of The Myth of the Eternal Return" (Collins 1998, p. 234). The overly simplistic Western ideas of Indian time are also critiqued in (Trautmann 2009). 
this soteriological turn in Upanișadic thought and to the demands of the new genre as the Upanișads gradually grow apart from the older Vedic corpus. ${ }^{2}$

In his study of time and space in the novel, the Russian literary critic Bakhtin coins the term chronotope and defines it as follows:

"We will give the name chronotope (literally, "time space") to the intrinsic connectedness of temporal and spatial relationships that are artistically expressed in nature". (Bakhtin 1981, p. 84)

Bakhtin's insight that each literary genre necessitates its own chronotope, or space-time, is, I think, a profound one that has application far beyond the study of European novels. I argue that the Upaniṣads, as an emergent genre of Hindu texts that is gradually differentiated from the older genres of the Vedas or the Brāhmanas, demands a shift in the literary conceptions of time as well. I propose that we can see within the Upanișads a very gradual transition from the older Vedic "ritual time", where both time and space are intimately connected with the performance of sacrificial rituals, to what we may call "ontological time", where time becomes a cosmic and ontological entity that takes its place alongside such philosophical concepts as being, ätman, and brahman, as part of a larger soteriological framework.

The most common term for time in the Rgveda is $r t u$, a word that is closely associated with the correct time for ritual performance. Kāla, which is the most commonly used term for time in the Upanișads, only occurs once in the Rgveda, in 10.42.9, where it also carries the sense of the correct moment for an action. Although time and ritual are often intertwined in the oldest Vedic texts, there are also passages in Vedic texts that hint at other, more complex notions of time, apart from the rhythms of the ritual calendar. When Rgveda 10.90.2 states that puruṣa, the primordial man, is "both what has been and what will be", ${ }^{3}$ this suggests the existence of a higher principle that encompasses all of time, an idea that will be further developed in the Upanișads. While the notion of abstract time as a cosmic principle is already present in the remarkable hymns to time $(k \bar{a} l a)$ in the emphAtharvaveda, ${ }^{4}$ which presents time as the creator of all things, this idea becomes more pervasive in the Upanisads as well. The Atharvaveda also hints at the existence of two forms of time, one associated with this world and one with the highest heaven. ${ }^{5}$ The Jaiminīya Brähmana similarly contrasts "whatever is on this side of the sun, night and day" with "immortality", which is located beyond the sun, ${ }^{6}$ which seems to imply a contrast between temporality and a different, atemporal state. For the most part, however, time in earlier Vedic literature is closely tied to the rhythms of the natural world and the performance of rituals. While these ideas are still found in the oldest Upaniṣads, several later Upanișadic texts elaborate on the ideas-present in germinal form in Vedic literature-of time as an abstract, cosmic power.

The Bṛhadäranyaka Upanișad, the oldest of the extant Upaniṣadic texts, fuses time and space into an integrated whole in the striking image that opens the text:

The dawn is the head of the sacrificial horse. The sun is its eye, the wind is its breath, and its open mouth is the fire common to all men. The year is the body (ätman) of the sacrificial horse, the sky is its back, the intermediate region is its belly, the earth is its underbelly, the quarters of the sky are its flanks, the intermediate quarters are its ribs, the seasons are its

2 While the earliest Upaniṣads are embedded in the textual traditions of the śākhās that transmitted them, and occasionally deeply connected with the Brāhmana texts of those śäkhās (as in the case of the Bṛhadārayaka, Aitareya, or Kena Upanișad), later Upanisads such as the Māndūkya do not have more than a nominal connection to the older Vedic textual corpus.

3 púruṣa evédám sárvam yád bhütám yác ca bháviyam. Text from (van Nooten and Holland 1994, p. 531).

4 Atharvaveda 19. 53-54. See the discussion in (Balslev 1992, p. 166).

5 Atharvaveda 19. 53.3: pūrn áh kumbhó 'dhi kālá ā'hitas ta'm vaí páśyāmo bahudhā' nú sā'ntam/sá imā'víśā bhú vanāni pratyán kālám tám āhúh paramé vyòman '"A full beaker is placed on Time. We see him being in many forms. He carries away all these beings. They call him Time in the highest heaven"); text from http://titus.uni-frankfurt.de/texte/etcs/ind/aind/ved/av/avs/avs.htm.

6 Jaiminīya Brāhmaṇa 1.11: sa yat kị̣ ca parācīnam ādityāt tad amṛtạ̣ [ . . . ] atha yad arvā̄iñam ādityād ahoratre tad. Text from Vira (1937, p. 5). 
limbs, the months and half-months are its joints, the days and nights are its feet, the stars are its bones, the clouds are its flesh, the sand is the food in its stomach, the rivers are its intestines, the hills are its liver and lungs, the plants and trees are its hairs, the rising sun is its front part, and the setting sun is its back part. (1.1)

This passage identifies various parts of the visible world—sun, wind, sky, stars, clouds, plantswith the body of a horse about to be ritually sacrificed, but it also views the year, the changing seasons, months and fortnights, days and nights, as parts of the same cosmic horse. The various measurements of time are here identified with the parts of the horse associated with movement, such as limbs, joints, and feet, but ultimately not separate from other parts of the cosmos. Time and space merge into one living being in this Upanișadic passage, inseparable parts of a whole. Significantly, time is here closely associated with both ritual and with calendrical divisions such as months, half-months, and years; time has not yet become an abstraction, separate from the rhythms of daily life.

The various calendrical divisions of time, such as day, night, fortnights, and months are part of the cosmic architecture of the worlds through which a person travels after death in Bṛhadäranyaka Upanișad 6.2.15-16. Here, a person of knowledge travels after death from the (funeral) fire to the day, to the fortnight of the waxing moon, to the six months when the sun travels north, and then to the world of the gods, the sun, and the region of lightning. The afterlife journey of a person who has no such knowledge but instead offers pious sacrifices, on the other hand, goes through smoke, night, the fortnight of the waning moon, the six months when the sun travels south, the world of the fathers, and the moon, and then back to the earth as rain. Significantly, divisions of time such as days, nights, and fortnights are here parts of the fabric of the cosmos itself, as much a part of the empirical world as the sun or the moon.

We can observe through the older Upanisads that time gradually becomes an abstraction, something apart from seasons, processes, and activities. In the Brhadāranyaka Upanișad, however, divisions of time such as past and future are still closely tied to ritual: "Saying "to what has been, svāhā!" he makes an offering in the fire and pours the rest into the mixture. Saying "to what will be, svāhāl" he makes an offering in the fire and pours the rest into the mixture" (6.3.3). ${ }^{8}$

The (ritual) year often functions as a stand-in for time in general in the Bṛhadaranyaka Upanișad, as in the creation myth narrated in 1.2.4:

He [Death] had a desire: "May a second body (ätman) be born for me!" With his mind, he had intercourse with speech, and Death had intercourse with hunger. That which was the semen became the year. Before that, the year did not exist." ${ }^{\prime \prime}$

How are we to interpret this curious image of time, here represented by the year, as the offspring of death, language, and hunger? Perhaps the underlying idea here is that our concept of time originates in a recognition of transience and decay (death), in conjunction with desire (hunger) and the ability of language to create abstractions. By assigning a mythological beginning to the year, and by implication to time itself, this Upanisad hints that time is not an eternally existing thing, but a construct.

However, the Brhadāranyaka Upanișad also speculates that time itself may be the origin of all things. In Bṛhadāranyaka Upaniṣad 1.5.14-15, the creator god Prajāpati is himself likened to the year and its components: "Prajāpati is the year, consisting of sixteen parts. His nights consist of fifteen parts, but

7 uṣa vā aśvasya medhyasya śirah. sūryaś cakṣur vātah prāno vyāttam agnir vaiśvānarah. saṃvatsara ātmāśvasya medhyasya. dyauh

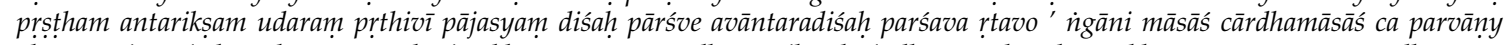
ahorātrāni pratișthā nakșatrāny asthīni nabho māmnsāny ūvadhyam sikatāh sindhavo gudā yakṛc ca klomānaś ca parvatā oșadhayaś ca vanaspatayaś ca lomāni. udyan pürvārdho nimlocañ jaghanārdhah. This and all following Sanskrit passages from the Upanișads cited here are based on the edition by Olivelle (1998) unless otherwise specified.

8 bhütāya svāhety agnau hutvā manthe saṃsravam avanayati. bhaviṣyate svāhety agnau hutvā manthe samsravam avanayati.

9 so 'kāmayata dvitī̄yo ma ātmā jāyeteti. sa manasā vācam mithunam samabhavad aśanāyām mrtyuh. tad yad reta āsît sa samvatsaro 'bhavat. na ha purā tatah samvatsara āsa. Olivelle $(1998$, p. 488) and Maue (1976) here follow the Mādhyamdina recension in reading aśanāyām instead of aśanāyāa, as the Kānva recension does. 
his sixteenth part is constant. With his nights, he waxes and wanes. On the night of the new moon he enters into all that has life, and is born again in the morning." 10 The creator god Prajāpati is here identified with time itself in the form of the year and its lunar months, ${ }^{11}$ which brings to mind the well-known hymn to time in the Atharvaveda 19.53, which identifies Time $(k \bar{a} l a)$ as the father of the creator god Prajāpati and claims time as the ultimate origin of all things. ${ }^{12}$ While some scholars such as the Iranist Mary Boyce have proposed that the "assimilation of Prajāpati into a Time-cosmology" may be a result of foreign, possibly Babylonian or Phoenician influence (Gonda 1982, p. 51, citing Boyce 1982, p. 152), it is perhaps simpler to see Prajāpati's association with time as a result of his role as cosmic creator. The idea that the creator god Prajāpati consists of sixteen parts can be traced back to the Vājasaneȳ Saṃhitā of the Yajurveda (8.36), cp. Śatapathabrāhmana 7.2.2.17. Since the number sixteen is frequently associated with totality in Vedic literature, it makes sense that the originator of all things is also made up of sixteen parts. However, in this passage from the Bṛhadāranyaka Upanișad, it is interesting to note that of the sixteen parts that make up the totality of the year, fifteen parts wax and wane, while one part remains constant (dhruva). This notion that time can be divided into a transient part and a constant, unchanging one, foreshadows the later Upanișadic idea that fleeting, transitory time can be contrasted with something eternal and timeless.

The Brihadâranyaka Upanișad also delves deeper into the idea of time as something closely intertwined with suffering. The lesser philosopher Aśvala observes in his debate with Yājñavalkya, the protagonist of the text, in Bṛhadāranyaka Upanisad 3.1.4 that "this whole world is gripped by days and nights"13 and asks how a patron of a sacrifice can free himself from this cruel grip of time. The movement of time is here explicitly tied to ritual, as so often in the older Vedic texts, but in this passage, time is also viewed as a form of suffering, something a person might wish to free himself from. In his response to Aśvala, the sage Yajjñavalkya points to principles beyond the mutations of time, such as fixed ritual roles and the sun, wind, and moon, timeless elements that offer comfort and stability to the person caught in the grip of time. However, later in the same text, Yãjñavalkya introduces Gārgī (apparently the only woman among the philosophers gathered at King Janaka's court to discuss the nature of the self) to the idea that the passage of time itself is under the command of a higher "imperishable" principle: "At the command of this imperishable, Gārgī, moments and hours, days and nights, half-months and months, seasons and years stand apart" (3.8.9). ${ }^{14}$ While Aśvala articulates the predicament of a person controlled by time, Yãjñavalkya points to a higher reality that controls time itself. Yājñavalkya argues in his dialogue with Gārgī that it is the self (ātman), "before which the year revolves, along with its days" (4.4.16), ${ }^{15}$ establishing the eternal, unchangeable nature of the ätman as something that is set apart from and higher than the passing of time.

In their dialogue about the ultimate origin of all things in Brhadàranyaka Upanișad 3.8, Gārgī pushes Yājñavalkya to explain the origins of both the material world and of time itself: "That which is above the sky, that which is below the earth, and that which is between heaven and earth, and that which they call past, present, and future—on what, Yājñavalkya, are these woven back and forth?"(3.8.6). ${ }^{16}$ Gārgī here uses the metaphor of weaving to indicate a cosmic construction of reality. Yājñavalkya's

10 sa eșa saṃvatsarah prajāpatih șodaśakalah. tasya rātraya eva pañcadaśa kalāh. dhruvaivāsya ṣodaśī kalā. sa rātribhir evā ca pūrvato 'pa

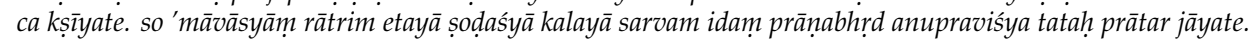

11 For a full discussion of the purusa/brahman consisting of sixteen parts, see (Mirasdar 1987).

12 Atharvaveda 19.53.8.

13 idạ̣ sarvam ahorätrābhyām äptam. While Radhakrishnan (Radhakrishnan 1994, p. 212) renders the verb āp as "pervade" here, the context suggests a more negative connotation. I am therefore following Olivelle (1998, p. 77) who translates "caught in the grip of" and Roebuck who translates it as "seized" (Roebuck 2000, p. 41).

14 etasya vā aksarasya praśāsane gārgi nimeșā muhūrtā ahorātrāny ardhamāsā māsā rtavah saṃvatsarā iti vidhrtās tișthanti. The words nimeșā muhūrtā ("moments and hours") are missing from the Mādhyamdina recension of the text.

15 yasmād arvāk samvatsaro 'hobhih parivartate. This is stanza 17 in the Mādhyamdina recension. I am here following the numbering of the Kānva recension.

16 yad ūrdhvam yājñavalkya divo yad avāk prthivyā yad antarā dyāoāoprthivī ime yad bhūtaṃ ca bhavac ca bhavisyac cety ācakṣate kasmims tad otam ca protam ceti. 
answer is that all of these things she lists, including the divisions of time such as past, present, and future are "woven back and forth" on space, hinting, perhaps, that he views space as the origin of time. However, the ultimate origin of all things, including both space and time is, according to Yãjñavalkya, the highest brahman itself. While some parts of the Bṛadāranyaka Upanișad still resonate with older notions of time as liturgical and ritual, we can also trace a gradual development of a notion of time as an ontological principle in this text, especially in the statements ascribed to Yãjñavalkya.

The Chāndogya Upanișad similarly posits that a higher reality exists beyond the mutations of time; this text claims that when someone "knows upanisad of brahman in this way-for him the sun does not rise or set; for him it is always day" (3.11.3). ${ }^{17}$ Here, timelessness is not just associated with brahman itself, but also with a person who possesses the correct knowledge of brahman. The idea that knowledge can help a human being access an eternal reality is of course central to all the Upanisads. In one of the few academic studies devoted to time and timelessness in the Upanișads, Yadav writes: "Thinking about the timeless Being is the fundamental activity of the being in time" (Yadav 1976, p. 327); in other words, true knowledge of brahman allows a timebound being to reach a reality that lies beyond all time.

The Chāndogya Upanisad further suggests that time and brahman belong to two entirely different modes of reality, separated by the ātman:

This self is a dam, a divider, to keep these worlds apart. Days and nights do not pass across this dam, and neither do old age, or death, sorrow, or good and bad deeds. All evil turns back from it, for this world of brahman is free from evil. (8.4.1) $)^{18}$

The idea that the divisions of time and old age and death have no access to the world of brahman indicates that brahman is located outside of time altogether. However, how are we to understand the image of $\bar{a} t m a n$, the self, that is the dividing line between these two realities? Perhaps what is implied here is the idea that the self of a human being belongs simultaneously to two different realities, the realms of time, death, and suffering, and the realm of the eternal.

While we still see some remnants of the idea of time as closely tied to days and nights and the rhythms of the physical world in the Chāndogya Upanișad, later classical Upanișads such as the Śvetāśvatara present time as something entirely distinct from the physical world. Here, time is no longer the ritual year or the passing of days and nights, but an abstract idea. This Upanișad speculates about the possible origin of brahman itself, the invisible cosmic force that permeates all things: "What is the cause of brahman? [ ... ] Should we think of it as time, self-nature, necessity, coincidence, the elements, birth, or the person (purusa)?" (1.1-2). ${ }^{19}$ The theory of time as the ultimate origin of all things is likely drawn from Atharvaveda 19.53-54, as discussed previously. This passage in the Śvetāśvatara Upanișad implies that a form of kālavāda, a doctrine of time as the highest principle and origin of all things, existed by the time this Upanișad was composed (Balslev 1992, p. 166; Panikkar 1992; Prasad 1992, p. 3).

However, while time is listed first among all the potential sources of brahman and of the world itself in the Śvetâśvatara Upaniṣad, this text ultimately rejects this idea of time as origin in favor of a personal god as the ultimate cause of the universe: "Some wise men say it is self-nature, but others, who are deluded, say it is time. But it is the greatness of god in the world by means of which this

17 na ha vā asmā udeti na nimlocati. sakrd divā haivāsmai bhavati. ya etām evam bhahmopanișadam veda. Coomaraswamy translates sakrddiva "once-and -for-all day" here, which conveys a sense of the timelessness of the day experienced by the one who knows the hidden teaching of brahman (Coomaraswamy 1947, p. 13).

18 atha ya ātmā sa setur vidhṛtir eșām lokānām asambhedāya. naitam setum ahorātre tarato na jarā na mrtyur na śoko na sukṛtam na duṣkrtam. sarve pāpmāno 'to nivartante.. apahatapāpmā hy eșā brahma-lokah. Radhakrishnan (Radhakrishnan 1994, p. 497) translates setu as "bridge" here, which does not make much sense in the context, since the setu is keeping two worlds apart. Olivelle translates "dike" (Olivelle 1998, p. 277) and Roebuck "dam" (Roebuck 2000, p. 196).

19 kiṃkāraṇam brahma [ ... ]kālah svabhāvo niyatir yadṛcchā bhūtāni yonih puruṣeti cintyam. I am here following Olivelle (1998, p. 615) in reading kimkäranạ̣ rather than kim kāranam. If kim is regarded as a separate word here, the meaning would be "What is the cause? Brahman?" as Radhakrishnan translates (Radhakrishnan 1994, p. 709). I am also following Olivelle in adopting the emendation of puruṣa iti to puruṣeti for the sake of the meter (Olivelle 1998, p. 615). 
wheel of brahman is turned around (6.1)."20 This god, Rudra-Śiva, is called the "architect of time" (kālakāra, 6.2 and 6.16), which suggests that time is here seen as part of creation itself rather than a cosmic cause. Rudra's creative work is here likened to that of a magician or an illusionist (māyin), and the list of things from which he creates the world includes the past and the future, as well as such ritual components as meters, sacrifices, rites, and religious observances (4.9), which hints that time itself is in this Upanișad simply a part of the material stuff of the universe. The creator/illusionist himself is, however, beyond time altogether; he is "beyond the three times" (i.e., past, present, and future, 6.5). Intriguingly, the very word for "illusion", māy $\bar{a}$, is connected with measurement; the noun is derived from the verbal root $m \bar{a}$, "to measure". While the term māy $\bar{a}$ usually means something as "creative power" or "the power to measure out space and time" in older Vedic language, māyā is clearly used in the sense of "illusion" in these stanzas of the Śvetāśvatara Upanișad, as in later Advaita-Vedānta philosophy. In stanza 4.10, māy $\bar{a}$ (illusion) is identified with primordial matter, while the illusionist that creates the world is identified with Rudra-Siva. The use of the significant term māya here hints that the measuring out of finite space and time is somehow the work of a divine illusionist and suggests that time is something associated with a fleeting existence in this world, rather than with the highest reality.

Moreover, while the god Rudra-Śiva is the creator of time in this Upanișad, he is also its destroyer: "For one is Rudra [ ... ] He stands opposite all beings. After drawing in all beings, he stands as the protector at the end of time." (3.2). ${ }^{21}$ The notion that time has an end, and that Rudra-Siva is instrumental in bringing it about is a radical innovation in this text, which foreshadows the later Hindu idea of Śiva as the destroyer at the end of a yuga, annihilating the universe before it is created anew.

While other classical Upanișads are less theistic than the Śvetāśvatara in their outlook, they also embrace the idea of a divine reality beyond time. The Māndūkya Upanișad proposes that the past, the present, and the future are all part of the sacred all-encompassing syllable om. However, this Upanișad also adds, intriguingly, that "whatever else that is beyond the three times, that is also just om (1). ${ }^{22}$ This idea that there is something located beyond the three times hints at a budding concept of the timeless, which will be further developed in later texts such as the Maitrī Upanișad. The Māndūkua Upanișad suggests that the past, present, future, and the timeless are all parts of the àtman, and that these four parts of the self also correspond to four states of consciousness: The waking state, sleep, dreamless sleep, and the mystical fourth, or turiya state. By implication, then, both time and timelessness are here regarded as aspects of both the self and of consciousness, and the timeless associated with the deepest form of consciousness. In a way, this is a re-articulation of the idea of the self located at the border between two realities that we saw in the Chāndogya Upanișad.

The Mahānārāyana Upaniṣad picks up on the Māndūkya Upanișad's ideas about the sacred syllable om and its relation to both time and timelessness. This Upanișad identifies om with the creator god Prajāpati, and argues that om is "whatever has been in the past and whatever is to come in the future" (1.2). ${ }^{23}$ However, the highest reality not only encompasses all of time, but is also posited as its origin:

All divisions of time were born from the lightning, from the person:

Minutes, hours, seconds, days and nights everywhere, and half-months, months, seasons, and the year. . . (1.8-9)2424sarve nimeșā jajñire vidyutah puruṣād adhi/ kalā muhūrtāh kāṣthāś cāhorātrāś ca sarvaśaḥ/ ardhamāsā māsā ṛtavaḥ samvvatsaraś ca.

svabhāvam eke kavayo vadanti kālam tathānye parimuhyamānāh. devasya eṣa mahimā tu loke yena idaṃ brāhmyate brahmacakram. I am here following Olivelle's reading, which restores the meter and reads devasya eșa and yena idam for devasyaișa and yenedam (Olivelle 1998, p. 626).

21 eko hi rudro [ ... ]pratyan் janāṃs tiṣthati saṃcukocāntakāle saṃsṛjya viśvā bhuvanāni gopāh..

22 yac cānyat trikālātìtam tad apy oṃkära eva.

23 tad eva bhütam tad u bhavyam. 
The Maitrī Upanișad revisits the older concept of time as closely tied to the physical world: "Food is the origin of all the world. Time is the origin of food. The sun is the origin of time" (6.14). ${ }^{25}$ The idea that time is the origin of food is perhaps based on the observation that it takes time for crops to grow and ripen, but this Upanișad also takes a more abstract view of time when it suggests that the sun itself is the origin of time, since "[w]ithout measure there is no knowledge of the thing to be measured" (6.14). ${ }^{26}$ This passage implies that we only have a concept of time because the shifting of days and nights gives us the ability to measure it. This does not necessarily mean that time is nothing but a human construct, but rather that we would be unable to know time if we could not measure it. The Maitri Upanișad further states that time is that which "cooks" (ripens) all living creatures (i.e., brings them to the end of their natural life cycle, 6.15), but also proposes that there is another reality that lies beyond time altogether: "Brahman has two forms: time and non-time" (6.15). ${ }^{27}$ This concept of a non-time ( $a k \bar{a} l a)$, something opposed to and distinct from time ( $k \bar{a} l a)$, implies that while the cosmic force brahman may be experienced in this world, there is also a part of brahman that lies beyond the empirical realm associated with the measurement of time, an idea that echoes that of the unchanging, sixteenth part of the year that we saw in the Brhadāranyaka Upanisad. ${ }^{28}$ Mandal $(1968$, p. 6) interprets this passage in the Maitri Upanișad as articulating a difference between empirical time and transcendental time. Here, Mandal's notion of "transcendental time" comes close to what Mahadevan (1976) and Yadav (1976) have called "timelessness", a form of unchanging reality that lies beyond the experiential world of suffering and decay.

The Maitrī Upanișad plays with the terms kāla ("time") and kala ("part, division") and uses the pun to make a larger theological point: "That which is before the sun is non-time, without parts. Of the partite (brahman) the form is the year." (6.15). ${ }^{29}$ The underlying idea here is that time is that which can be measured by the movement of the sun and the division into days and nights, while there also exists a timeless, unmeasurable aspect of the same cosmic reality of brahman. Time itself is, as Mahadevan observes, "one of the principal forms of the supreme, immortal, unembodied Brahman (Mahadevan 1976, p. 327); but the other principal form of brahman is timeless."

From around the 12th century of the common era, new kinds of Upanisads begin to flourish. These texts, often called Śākta Upanișads, ("Upaniṣads of Power") or Devī Upanișads ("goddess Upaniṣads") are devoted to Hindu goddesses, who are seen as manifestations of the divine power, śakti, and identified with brahman itself. A distinction similar to that in the Maitri Upanișad between measured time and a radically different, atemporal form of reality is also hinted at in the Devi Upanisad: "She [the goddess] is the divisions of time, and the form of primordial time (ädikālarūpin $\bar{\imath}) . "(18) .{ }^{30}$ "Primordial time" is here distinct from the time that can be measured and divided, and associated with a higher immutable reality, that of the all-encompassing goddess.

The idea of atman/brahman or a deity as a reality beyond time itself is closely intertwined with the notion of the highest reality as independent of causality (Deussen 1987, p. 154ff). When the Bṛhadāranyaka Upaniṣad 4.4.22 refers to ātman as "unborn" (aja) and "undecaying" (aśîrya), for example, this places the supreme a atman/brahman both beyond the ravages of time, but also apart from any chain of causality that involves changes over time, such as coming into being and decaying. Rather, the uncaused and eternal atman/brahman is itself regarded as the ultimate cause and origin of all things. When the Maitri Upanișad states that brahman is both time and non-time, this suggests that there is nevertheless an aspect of the timeless, unchanging brahman present in the conditioned world of time and change. Jay Kumar has attempted to demonstrate that Upanișads' idea that consciousness exists 
simultaneously at the infinite, timeless, non-local level and in the finite, temporally bound, localized realm aligns with certain principles of quantum theory (Kumar 2014, p. 422). While this reading of the Upanișadic passages that deal with time and timelessness is perhaps a bit of a stretch, I think Kumar's insight that human consciousness is simultaneously bound by time and timeless is very much in accordance with the world view of the Upanisadic authors.

Eliade, on the other hand, interprets the term "non-time" in the Maitri Upanișad as a reference to the sacred, primordial moment which he calls Great Time, as opposed to profane time (Eliade 1958, pp. 186-87) According to Eliade, "[t]his mythical or sacred time is qualitatively different from profane time, from the continuous and irreversible time of our everyday desacralized existence" (Eliade 1958, p. 173). For Eliade, this passage is key to understanding Hindu thought, and he writes: "To transcend profane time, to recover the mythical Great Time, is equivalent to a revelation of ultimate reality" (Eliade 1958, p. 173). While Eliade goes much too far in superimposing his own idiosyncratic views of time and eternity on the Indian texts, there can be no question that most of the later classical Upanisads operate with the idea of a highest reality outside of all time. I am not sure, however, that Eliade is correct in associating this sacred reality with the mythic past and a primordial illud tempus (Eliade 1954, p. $76 ; 1959$, p. $68 f f ; 1961$, p. $15 ; 1977$, p. 16); rather, the highest reality as it is described in many of the classical Upanisads is, I would argue, outside of time altogether.

Although eternity —as an abstract noun—is not a term that is often used in Hindu philosophy, the idea of the eternal is nevertheless easy to identify in the classical Upanișads.

Brahman is, for example, specifically called eternal, sanātana, in Katha Upanișad 5.6 and Mundaka Upanișad 1.1.6. The frequent references to brahman as imperishable (akșara) in the Upaniṣads similarly suggest that brahman is beyond all mutations of time. Brahman is "the lord of what was and what will be; he is both today and tomorrow" (Katha Upanișad 4.13). ${ }^{31}$ The ätman is also described as "without beginning or end, beyond the great, and eternal" (Kața Upanișad 3.15) 32 while the sacred syllable om is likewise referred to as "different from what has been and what will be" (Katha Upanisad 2.14). ${ }^{33}$ The classical Upanișads cited here often play with the term akșara, which can mean both "syllable" and "imperishable". The syllable om is akșara in both senses of the word; it is a sacred syllable associated with an unchanging reality beyond time. When U. C. Bhattacharya argues that in ancient Indian thought "change and becoming were a degradation of eternity, which was conceived as changeless and motionless" (Bhattacharya 1937, p. 72), this is certainly true of the later Upanișads.

This paper argues that we can trace through the Upanisads a gradual process of untangling the idea of time from the rhythms of the natural world, the changing seasons, and the ritual year, a process that already began in the Hymns to Time in the Atharvaveda. This abstraction of time parallels other abstractions in the Upanisads. The idea of a tman, the self of a living being, begins with a notion of self that is indistinguishable from the physical body in some passages in the older Upanișads ${ }^{34}$ and gradually becomes a transcendent and wholly immaterial entity as distinct from the body. Similarly, the notion of time comes to transcend the physical realities of seasons and days and nights and becomes an abstract philosophical concept in the Upanișads. This shift in Upanișadic notions of time, I suggest, is intricately connected to the gradual separation of the Upanișads from the corpus of the Vedic ritual texts and their eventual emergence as a new genre of Hindu texts, a genre that demands new notions of space and time. Bakhtin's theory of the chronotope, the artistic space-time of literary narratives, is quite helpful here. Bakhtin proposes that the chronotope, and particularly the temporal component, defines and shapes a literary work; specific notions of time are inextricably linked to textual genres. I suggest that this idea that each form of literature embodies particular genre-specific ideas about time

31 Olivelle (1998, p. 395) translates "the same today and tomorrow", but I am choosing to render the text more literally here.

32 anādy anantam mahatah param dhruvam.

33 anyatra bhūtāc ca bhavyā c ca.

34 See for example Bṛhadāranyaka Upaniṣad 1.1.1, 1.2.1, 1.2.3-5, 1.2.7, 1.4.4, 1.5.21, 1.6.3, and 2.4.4, Chāndogya Upaniṣad 1.2.14, 1.6.3, 1.7.1, 3.18.1, 4.4.4, 8.8.1, and 8.8.4, Aitareya Upaniṣad 2.2, and Kaușitaki Upaniṣad 2.12, 4.2, and 4.10. 
and space can be fruitfully applied to late Vedic literature as well. In the oldest Upanișads, we still see an older notion of liturgical and ritual time, echoing the rhythms of the natural year, while time becomes more abstract as the Upanișads refine their narratives of transcendence and grow increasingly occupied with a higher reality behind the visible forms of the natural world.

However, why did these ideas about time and transcendence arise in these specific Upanișads? I argue that one of the answers to this question must be sought in the Upanisads' lingering association with Vedic ritual. The Upanișads were transmitted orally by schools, or śákhās, or Vedic recitation. Each of the classical Upanișads is therefore formally affiliated with one of the four Vedas, the oldest texts of Hinduism. The affiliation between an Upanișadic text and an older Vedic text is actually far more than a mere formality, although these affiliations have often been given too little attention in modern scholarship (Bausch 2015; Cohen 2018b, p. 21). Each śākhā was responsible for memorizing and transmitting one of the four Vedas, as well as the later texts affiliated with it, including the śa $k h \bar{a}^{\prime} s$ Upanișads. Each Upanișad was likely composed by authors who had memorized one particular Vedic text, and who were also specialists assigned particular roles during the intricate Vedic rituals. The hotr, or Rgveda priest, was in charge of invoking the gods during the Vedic ritual, the udgattr, or Sāmaveda priest would chant, the adhvaryu or Yajurveda priest was responsible for any practical ritual actions-and later, a fourth priest, the brahman, associated with the Atharvaveda, was charged with supervising the ritual as a whole. I argue that in the oldest Upanișads, the concerns of the śäkhās that composed them still resonate through the texts. Thus, the Upanisads affiliated with the Rgveda include numerous references to the Vedic gods, the Upanișads of the Sämaveda are preoccupied with songs and chants and sacred sounds, while the Upanișads of the Yajurveda are particularly concerned with ritual actions (karma) and their results. Many of the new ideas that emerge in the Upanisads, such as the doctrine of karma as a cosmic law of action and reaction, grow out of Upanișadic elaborations on śa $k h \bar{a}$-specific concerns (see Bausch 2015). What about the new Upanișadic ideas of time? Can they also be traced back to a particular śäkhē? While meditations on the concept of time is found sporadically in Upanisads affiliated with all the Vedas, we may note that most of the radically innovative ideas about time in the Upanișads are found in texts affiliated with the Yajurveda, such as the Brhadäranyaka, Kațha, Śvetāśvatara, and Maitrī. This is where we first encounter such new concepts as the passage of time being associated with suffering, the existence of a higher principle beyond time, a personal deity as the creator of time, the idea of an eventual end of time, as well as concepts of non-time and timelessness. I suggest that the reason why these ideas develop in these particular Upanisads can be found precisely in the texts' connection with the Yajurveda and the role of the adhvaryu priests.

As we have seen, the older Vedic ideas of time were often-although not always-associated with ritual action. This notion of time as essential for ritual is especially prevalent in the Brāhmana literature, where kâla is often used to designate the precise moment for a ritual act. This usage is particularly prevalent in the Śatapathabrāhmana ${ }^{35}$ which belongs to the White Yajurveda. One may speculate that the adhvaryu priests who composed this Brāhmana with its detailed descriptions of the minutiae of ritual preparations and the correct time for those actions may have begun to think more deeply about the nature of both time and action. It is interesting to note that innovative ideas about both time and action (karma) arise out of the later philosophical literature affiliated with the Yajurveda, such as the Bṛ̂adāranyaka, Kațha, Śvetāśvatara, and Maitrī Upanișads.

In her insightful study of the cultural milieu in the Kosala region of Eastern India in which the Kannva school of the White Yajurveda flourished, Bausch (2015) has demonstrated that a "Kosalan philosophy" associated with theories of causality and modes of knowing permeates both the Hindu ritual text Śatapatha Brāhmana and the Buddhist Suttanipāta. ${ }^{36}$ While Bausch's work focuses specifically on the Kānva school of the White Yajurveda and its influence on later Indian thought, I argue that some

35 See for example Śatapathabrāhmana 1.7.3.3; 2.1.3.4; 2.4.2.4; 3.8.3.36; 7.2.2.21.

36 Bausch builds on Bronkhorst's seminal work (Bronkhorst 2007) which identifies the aspects of the local culture of the Magadha region as profoundly influential in the formation of both Upanișadic philosophy and Buddhist and Jain thought. 
of the most important developments of ideas of time can be found in the Upanisads affiliated with both the White and the Black Yajurveda. I propose that the some of the changes in the conceptions of time that we can observe in the Upanisads can be traced back to an internal development in speculations surrounding kāla in the Upanișads affiliated with the Yajurveda, coupled with a general tendency in the Upanișads towards a greater level of abstract speculation.

Across the Upanisadic texts, we can see an intense preoccupation with the true nature of reality, which may even be indicated by the very name of the genre. The commonly accepted explanation of "Upanișad" as "sitting down near" (upa-ni-sad) the feet of a teacher is likely incorrect; rather, the term is better translated as "that which lies (sad) beneath" or "underlying reality" (Cohen 2008, pp. 2-3; 2018a, p. 2) ${ }^{37}$ It is possible that the genre name Upanisad is derived precisely from the texts' preoccupation with an eternal, unchanging reality underlying all the shifting, changeable forms of the physical world: The eternal atman within the mortal body, the immutable brahman behind all physical forms, the enduring law of karma underlying all individual ritual and secular acts. The Upanișadic authors seek the unconditioned reality underlying the conditioned world, including the divine and timeless $\bar{a} t m a n / b r a h m a n$ that can be glimpsed beyond the rhythms and movements of conditioned time.

The Indo-Spanish philosopher and theologian Raimundo Panikkar in his musings on time in Hinduism, speaks poetically of man as a "time-ridden being", seeking to "shed his temporal skin" (Panikkar 1978, p. 686). From the Upanișads onwards, Hindu philosophy posits two radically different modes of existence: A conditioned form of being associated with time and with suffering, and a state of radical otherness associated with liberation and timelessness. I suggest that the development of this concept of a timeless state is closely tied to the new views of both time and human beings that develop in the Upanișads: No longer part of the rhythms of ritual and seasons, no longer defined by body and breath, human beings are now, above all, defined as ätman, a self that has "shed its temporal skin".

While the earliest Upaniṣads are often concerned with ritual time, as are the Brāhmanas that precede them, later Upanișadic texts are increasingly preoccupied with the invisible, transcendent reality behind and beyond the visible forms of this world. Over time, time itself is perceived as one such form of transcendent reality, and ultimately, as a gateway to an even higher reality beyond. As we have seen, some of the most important reorientations in the Upanisadic conceptions of time are found in the Upanișads formally affiliated with the Yajurveda. I see these innovations as partly as

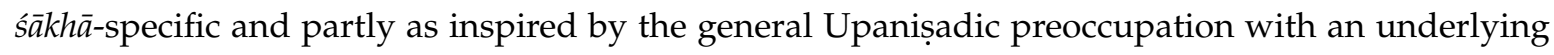
reality, as the very name of the genre implies; the emerging genre of the Upanișads is one that demands a greater focus on the transcendent. Just as karma has become a cosmic causality rather than a mere sacrificial action in the Upanișads, and ātman an eternal principle rather than a physical body, so time becomes an abstract principle, rather than a mere ritual moment. The abstraction of time, just like the abstraction of karma or ātman, is part of a larger turning of the literary gaze away from the empirical world and toward the underlying reality, the timeless brahman itself. The nascent Upanișadic genre demands a chronotope that regards empirical time as a gateway to a timeless reality beyond.

Conflicts of Interest: The author declares no conflict of interest.

\section{References}

Bakhtin, Mikhail. 1981. Form of Time and Chronotope in the Novel. In The Dialogic Imagination: Four Essays. Translated by Caryl Emerson, and Michael Holquist. Austin: University of Texas Press, pp. 84-258.

Balslev, Anindita N. 1992. Time and the Hindu Experience. In Religion and Time. Edited by Anindita N. Balslev and J. N. Mohanty. Leiden: Brill, pp. 163-81.

Bausch, Lauren M. 2015. Kosalan Philosophy in the Kāṇva Śatapatha Brāhmaṇa and the Suttanipāta. Ph.D. dissertation, University of California, Berkeley, CA, USA.

37 Cp. Olivelle's translation "hidden connection" (1998 passim). 
Bhaduri, Sadananda. 1975. Studies in Nyāya-Vaiśeșika Metaphysics. Poona: Bhandarkar Oriental Research Institute. Bhattacharya, U. C. 1937. Space, Time, and Brahma. Poona Oriental Series 39: 69-85.

Bhattacharya, Deviprasad. 1965. A Short Note on Time. Calcutta Review 175: 45-46.

Boyce, Mary. 1982. A History of Zoroastrianism II. Leiden: Brill.

Bronkhorst, Johannes. 2007. Greater Magadha: Studies in the Culture of Early India. Leiden: Brill.

Cohen, Signe. 2008. Text and Authority in the Older Upanișads. Leiden: Brill.

Cohen, Signe. 2018a. Introduction: What is an Upanișad? In The Upanișads: A Complete Guide. Edited by Signe Cohen. London and New York: Routledge, pp. 1-8.

Cohen, Signe. 2018b. The Authorship of the Upanișads. In The Upanișads: A Complete Guide. Edited by Signe Cohen. London and New York: Routledge, pp. 18-24.

Collins, Steven. 1998. Nirvana and Other Buddhist Felicities: Utopias of the Pali Imaginaire. Cambridge: Cambridge University Press.

Coomaraswamy, Ananda. 1947. Time and Eternity. Ascona: Artibus Asia.

Das, Sukumar Ranjan. 1933. Notion of Time in Indian Philosophy. Indian Historical Quarterly 9: 149-53.

Deussen, Paul. 1987. Sixty Upanișads of the Veda. Translated by V. M. Bedekar, and Gajanan Balkrishna Palsule. Delhi: Motilal Banarsidass, Vol. 1.

Eliade, Mircea. 1954. The Myth of the Eternal Return: Cosmos and History. New York: Harper.

Eliade, Mircea. 1958. Time and Eternity in Indian Thought. In Man and Time. Edited by Joseph Campbell. London: Routledge \& Kegan Paul, pp. 173-200.

Eliade, Mircea. 1959. The Sacred and the Profane: The Nature of Religion. New York: Harcourt, Brace \& World.

Eliade, Mircea. 1961. Myths, Dreams, and Mysteries. London: Harvill.

Eliade, Mircea. 1977. No Souvenirs. New York: Harper and Row.

Gonda, Jan. 1982. In the Beginning. Annals of the Oriental Research Institute, Baroda 63: 43-62.

Gonzalez-Reimann, L. 2002. The Mahābhārata and the Yugas: India's Great Epic Poem and the Hindu System of World Ages. New York: Peter Lang.

Gupta, S. K. 1973. Concept of Time-East and West. The Journal of the Indian Academy of Philosophy 12: 29-40.

Herbert, Gundala Samuel. 1963. Time in Indian Philosophy. Sri Venkatesvara University Oriental Journal (Tirupati) 6: 22-31.

Hiriyanna, M. 1939. Advaitic Conception of Time. Poona Orientalist 4: 47-48.

Kumar, Jay. 2014. Temporal Non-Locality and the Cognitive Perception of Happiness: From the Upanishads to Quantum Theory. Cosmology 18: 422-42.

Lannoy, Richard. 1974. The Speaking Tree. London: Oxford University Press.

Mahadevan, Telliyavaram Mahadevan Ponnambalam. 1976. Time and Timelessness. Journal of Dharma 1: 324-30.

Mahadevan, Telliyavaram Mahadevan Ponnambalam. 1977. Time and the Timeless. In Contemporary Indian Philosophers of History. Edited by Telliyavaram Mahadevan Ponnambalam Mahadevan and Grace E. Cairns. Calcutta: The World Press, pp. 203-32.

Mandal, Kumar K. 1968. A Comparative Study of the Concepts of Space and Time in Indian Thought. Varanasi: Chowkhamba. Varanasi: Chowkhamba.

Maue, D. 1976. Bṛhadāraṇyakopaniṣad 1: Versuch einer kritischen Ausgabe nach akzentuirten Handschriften der Kāṇva-Reszension mit einer Einleitung und Anmerkungen. Ph.D. dissertation, University of Gießen, Gießen, Germany.

Mirasdar, Mangala. 1987. Șoḍaśakala Purușa: A Study. Vishveshvaranand Indological Journal 25: 90-98.

Olivelle, Patrick. 1998. The Early Upanișads. New York and Oxford: Oxford University Press.

Panikkar, Raimundo. 1978. Time and Sacrifice-The Sacrifice of Time and the Ritual of Modernity. In The Study of Time, III. Edited by Julius Thomas Fraser. New York: Springer, pp. 683-727.

Panikkar, Raimundo. 1992. Time and History in the Tradition of India: Kala and Karma. In Time in Indian Philosophy: A Collection of Essays. Edited by Hari Shankar Prasad. Delhi: Sri Satguru Publications, pp. 21-46.

Prasad, Hari Shankar. 1992. The Problem of Time in Indian Philosophy: An Introduction. In Time in Indian Philosophy: A Collection of Essays. Edited by Hari Shankar Prasad. Delhi: Sri Satguru Publications, pp. 1-20.

Radhakrishnan, Sarvepalli. 1994. The Principal Upanișads. New Delhi: Indus. First published 1953.

Roebuck, Valerie J. 2000. The Upanișads. London: Penguin Books.

Sastri, A. Mahadeva. 1950. The Śākta Upanișads with the Commentary of Śrī Upaniṣad-Brahma-Yogin. Madras: The Adyar Library. 
Sen, Sanat Kumar. 1968. Time in Sāṃkhya-Yoga. International Philosophical Quarterly 8: 406-26. [CrossRef] Sharma, Arvind. 1974. The Notion of Cyclical Time in Hinduism. Contributions to Asian Studies 5: 26-35.

Trautmann, Thomas R. 2009. Indian Time, European Time. In The Clash of Chronologies: Ancient India in the Modern World. Edited by Thomas R. Trautmann. New Delhi: Yoda Press.

van Buitenen, Johannes A. B. 1962. The Maitrāyaṇīya Upanișad. 'S-Gravenhage: Mouton.

van Nooten, Barend A., and Gary B. Holland. 1994. Rig Veda: A Metrically Restored Text. Cambridge: Harvard University Press.

Vira, Raghu. 1937. Jaiminīya Brāhmana of the Sāma Veda. Lahore: Arya Bharati Press.

Yadav, Bibhuti. 1976. The Question of Time and the Timeless. Journal of Dharma 1: 345-62.

(C) 2020 by the author. Licensee MDPI, Basel, Switzerland. This article is an open access article distributed under the terms and conditions of the Creative Commons Attribution (CC BY) license (http://creativecommons.org/licenses/by/4.0/). 